\title{
Integrative description of new giant pill-millipedes from southern Thailand (Diplopoda, Sphaerotheriida, Zephroniidae)
}

\author{
Trine ROSENMEJER ${ }^{\circledR 1}{ }^{1}$, Henrik ENGHOFF ${ }^{\circledR 2, *}$, Leif MORITZ ${ }^{\circledR 3} \&$ Thomas WESENER ${ }^{\circledR} 4$ \\ ${ }^{1,2}$ Natural History Museum of Denmark, University of Copenhagen, Universitetsparken 15, \\ DK-2100 Copenhagen OE, Denmark. \\ ${ }^{3,4}$ Zoological Research Museum Alexander Koenig, Leibniz Institute for Animal Biodiversity, \\ Adenauerallee 160, D-53113 Bonn, Germany. \\ ${ }^{3}$ Institute of Evolutionary Biology and Ecology, University of Bonn, An der Immenburg 1, \\ 53121 Bonn, Germany. \\ *Corresponding author: henghoff@snm.ku.dk \\ ${ }^{1}$ Email: trinehansen@hotmail.com \\ ${ }^{3}$ Email: moritz.leif@gmail.com \\ 르ail: twesener@leibniz-zfmk.de

\footnotetext{
${ }^{1}$ urn:1sid:zoobank.org:author:F9E1E73B-E6D8-46D7-B470-05E91142C98F

${ }^{2}$ urn:lsid:zoobank.org:author:9B9D901F-D6C8-4BCA-B11B-CF6EE85B16DC

${ }^{3}$ urn:Isid:zoobank.org:author:89921EE8-F015-4FED-AB5C-1D17F2C2F8F6

${ }^{4}$ urn:lsid:zoobank.org:author:86DEA7CD-988C-43EC-B9D6-C51000595B47
}

\begin{abstract}
Two new species of giant pill-millipedes, Zephronia viridisoma Rosenmejer \& Wesener sp. nov. and Sphaerobelum aesculus Rosenmejer \& Wesener sp. nov., are described based on museum samples from southern Thailand. Zephronia viridisoma sp. nov. comes from Khao Lak, while the type locality of $S$. aesculus sp. nov. is on Phuket Island. Both species are described integratively, combining light microscopy, scanning electron microscopy, multi-layer photography, micro-CT scans and genetic barcoding. Genetic barcoding was successfully conducted for holotypes of both new species, which could be added to a dataset of all published sequences of the family Zephroniidae, including all described species from Thailand, Laos and Cambodia up to 2020. Genetic barcoding of the COI gene revealed another female of $S$. aesculus sp. nov., $160 \mathrm{~km}$ east of the type locality. Both new species are genetically distant from all other Zephroniidae from Thailand and surrounding countries, showing uncorrected p-distances of $16.8-23.1 \%$. A virtual cybertype of a paratype of $Z$. viridisoma sp. nov. was created and made publically accessible.
\end{abstract}

Keywords. Cybertype, CT Scan, DNA Barcoding, biodiversity, soil fauna.

Rosenmejer T., Enghoff H., Moritz L. \& Wesener T. 2021. Integrative description of new giant pill-millipedes from southern Thailand (Diplopoda, Sphaerotheriida, Zephroniidae). European Journal of Taxonomy 762: 108-132. https://doi.org/10.5852/ejt.2021.762.1457 


\section{Introduction}

Thailand harbours an extremely rich and highly endemic biota. This unique biodiversity, which to a high extent is associated with limestone karsts, is under threat, mainly from anthropogenic habitat destruction. There is thus a race against time to describe and protect the microendemic Thai endangered fauna (Clements et al. 2006). Millipedes (Diplopoda) constitute a conspicuous element in Thailand's biodiversity, including some of the largest terrestrial invertebrates, as well as many strikingly coloured species; see, e.g., Enghoff et al. (2007), Srisonchai et al. (2016) and Pimvichai et al. (2018). The millipede fauna of Thailand has received considerable attention in recent years. From the time when the first species were recorded from "Siam" by Karsch (1881) and until the first comprehensive list of Thai millipedes was published by Enghoff (2005), 105 species had been recorded, but due to a massive effort by Professor Somsak Panha and his (now former) students from Chulalongkorn University in Bangkok, in collaboration with foreign specialists, the following 14 years saw a dramatic increase to 228 species (Likhitrakarn et al. 2019), and the number is still growing: with the contributions by Pimvichai et al. (2020), Wesener et al. (2021) and Likhitrakarn et al. (2021), and including the two species described here, 243 millipede species are now known from Thailand. The increased knowledge of Thai millipedes has mainly concerned the orders Polydesmida Leach, 1815, Spirobolida Bollman, 1893 and Spirostreptida Brandt, 1833. In contrast, the giant pill-millipedes, order Sphaerotheriida Brandt, 1833, have largely been neglected although they are common and apparently very diverse in Thailand. Until now, only five species of Sphaerotheriida have been recorded from Thailand, viz., Zephronia siamensis Hirst, 1907 (Hirst 1907), Z. cf. viridescens Attems, 1936 (recorded by Wongthamwanich et al. 2013), Sphaerobelum truncatum Wongthamwanich, 2012 (Wongthamwanich et al. 2012), and - very recently - Zephronia lannaensis Likhitrakarn \& Golovatch, 2021, and Z. phrain Likhitrakarn \& Golovatch, 2021 (Likhitrakarn et al. 2021).

The present paper is a first step of an effort to bring the knowledge of the Thai giant pill-millipede fauna up to a similar level as those of neighbouring Vietnam (e.g., Semenyuk et al. 2020) and Laos (Wesener 2019). We describe two new giant pill-millipede species from Thailand integratively, combining morphology with genetic barcodes, and creating a freely accessible cybertype for one of the new species.

\section{Material and methods}

\section{Specimens}

Details of the studied specimens, which were all hand-collected, are summarized in Table 1.

\section{Abbreviations}

ATOL $=$ Assembling the Tree Of Life project

$\mathrm{CT}=$ computer tomography

MHNG = Muséum d'Histoire naturelle de la Ville de Genève, Geneva, Switzerland

NHMD $=$ Natural History Museum of Denmark, University of Copenhagen, Denmark

SEM = scanning electron microscopy

ZFMK = Zoological Research Museum A. Koenig, Leibniz Institute for Animal Biodiversity, Bonn, Germany

\section{Map}

The localities of the described species were mapped in QGis ver. 3.8.0 Zanzibar (QGIS Development Team 2018). 
Table 1. Morphologically analysed specimens.

\begin{tabular}{|c|c|c|c|}
\hline $\begin{array}{l}\text { Sphaerobelum aesculus } \\
\text { Rosenmejer \& Wesener } \\
\text { sp. nov. }\end{array}$ & holotype, $\widehat{o}^{\lambda}$ & $\begin{array}{l}\text { THAILAND, Phuket Island, Forest in Kathu district; } \\
14 \text { Feb. 1989. M. Andersen \& A. R. Rasmussen leg.; } \\
\text { in \& under old logs. }\end{array}$ & NHMD 621693 \\
\hline $\begin{array}{l}\text { Sphaerobelum aesculus } \\
\text { Rosenmejer \& Wesener } \\
\text { sp. nov. }\end{array}$ & non-type, $q$ & $\begin{array}{l}\text { THAILAND, Nakhon Si Thammarat Prov., Khao } \\
\text { Luang NP; 8 } 43^{\prime} 25.2^{\prime \prime} \text { N, } 99^{\circ} 40^{\prime} 7.7^{\prime \prime} \text { E, } 355 \text { m a.s.l.; } \\
\text { 10-12 Oct 2003; ATOL Expedition } 2003 \text { leg. }\end{array}$ & NHMD 621694 \\
\hline $\begin{array}{l}\text { Zephronia viridisoma } \\
\text { Rosenmejer \& Wesener } \\
\text { sp. nov. }\end{array}$ & holotype, $\widehat{\jmath}$ & $\begin{array}{l}\text { THAILAND, Nakhon Si Thammarat Province, Sichon } \\
\text { District, Khao Lark Waterfall; } 9^{\circ} 03^{\prime} 6^{\prime \prime} \text { N, } 99^{\circ} 47^{\prime} 24^{\prime \prime} \text { E; } \\
25 \text { Aug. 2007; Chulalongkorn. Univ. Exp. leg.; dense } \\
\text { jungle on limestone. }\end{array}$ & NHMD 621695 \\
\hline $\begin{array}{l}\text { Zephronia viridisoma } \\
\text { Rosenmejer \& Wesener } \\
\text { sp. nov. }\end{array}$ & $\begin{array}{l}\text { paratypes, } \\
2 \hat{\delta}, 4+q\end{array}$ & Same data as holotype. & NHMD 621696 \\
\hline $\begin{array}{l}\text { Zephronia viridisoma } \\
\text { Rosenmejer \& Wesener } \\
\text { sp. nov. }\end{array}$ & paratype, $\widehat{\partial}$ & Same data as holotype. & ZFMK MYR8786 \\
\hline $\begin{array}{l}\text { Zephronia viridisoma } \\
\text { Rosenmejer \& Wesener } \\
\text { sp. nov. }\end{array}$ & paratype, + & Same data as holotype. CT scan voucher. & ZFMK MYR8787 \\
\hline
\end{tabular}

\section{Dissecting, light microscopy, illustrations}

Dissecting and pencil drawings were done under a Zeiss Discovery V8 with a camera lucida. Illustrations were produced by hand on paper, with a camera lucida mounted on a Zeiss Discovery V8. Drawings were afterwards scanned, and digitally touched up. All illustrations and pictures were edited in Adobe Photoshop CC. The backgrounds have been smoothed out, to reduce any disruptive visuals and to make them more similar in overall appearance. All terminology follows the recent literature (Wesener 2016a).

\section{Scanning electron microscopy}

For scanning electron microscopy (SEM), the endotergum and head were dissected. The samples were cleaned and dehydrated via an ethanol series $(2 \times 96 \%, 3 \times 100 \%)$ before being mounted on aluminum stubs and dried overnight. The stub was sputter-coated with gold in a Cressington 108 auto sputter coater. Images were obtained using a Zeiss Sigma 300 VP SEM at the ZFMK. After the study, dry coated SEM material was removed from stubs and returned to alcohol.

\section{Micro-computed tomography}

Volumetric data from a female paratype of Zephronia viridisoma Rosenmejer \& Wesener sp. nov. (ZFMK MYR8787) in $75 \%$ ethanol was obtained using micro-computed tomography (micro-CT). Micro-CT data was obtained with a SkyScan 1272 (Bruker microCT, Kontich, Belgium) at the ZFMK using the following scanning parameters: source voltage $=60 \mathrm{kV}$, source current $=160 \mu \mathrm{A}$, filter $=\mathrm{AL} 0.5 \mathrm{~mm}$, pixel size $=6.515728 \mu \mathrm{m}$, exposure $=2508 \mathrm{~ms}$, rotation $=180^{\circ}$, rotation step $=0.1^{\circ}$, averaging $=7$, random movement $=15$, flat field correction $=\mathrm{ON}$, geometrical correction $=$ on. Digital sections were recnstructed with NRecon ver. 1.7 (Bruker microCT, Kontich, Belgium) and modified in Fiji Image J 1.52g (Schindelin et al. 2012). Volume rendering was performed in Drishti ver. 2.6.3 (Limaye 2012). The image sequence of the reconstructed micro-CT-scan, i.e., the cybertype, is deposited in Zenodo and can be accessed by https://doi.org/10.5281/zenodo.4548243. The Voucher is stored at ZFMK (ZFMK MYR8787). 


\section{DNA barcoding}

In order to help with identifying related species, identifying females, and investigate the intraspecific and interspecific genetic (COI) distances, a molecular genetic barcoding study (Hebert et al. 2003) was conducted. DNA extraction, amplification, and sequencing of the cytochrome c oxidase subunit 1 (COI) gene was done as in previous studies (Sagorny \& Wesener 2017; Wesener 2019), using the degenerate primer pair HCO-JJ/LCO-JJ (HCOJJ AWACTTCVGGRTGVCCAAARAATCA / LCOJJ CHACWAAYCATAAAGATATYGG) (Astrin \& Stüben 2008). BLAST searches (Altschul et al. 1997) were performed as nucleotide blast on 19 July 2019 to confirm sequence identities and to check for contaminations. Sequences were concatenated by hand or utilizing the software Seqman (DNASTAR Inc.). The whole dataset was translated into amino acids to rule-out the accidental amplification of pseudogenes. The six new sequences have been uploaded to GenBank under the accession codes MW898737-MW898742 (Table 2).

\section{Phylogenetic and distance analyses}

The six new COI sequences were added to a dataset from a previous study, containing all published sequences of the Zephroniidae Gray, 1843 (as per June 2020) in addition to far and near outgroups (Wesener 2019). All sequences were aligned in Bioedit (Hall 1999). The final dataset contained 34 terminals (Table 1) and 671 base pairs as four base pairs were excluded because of too much missing data.

The number of base differences per site between sequences (p-distances) was calculated (see Supp. file 1). Codon positions included were $1^{\text {st }}+2^{\text {nd }}+3^{\text {rd }}$. All ambiguous positions were removed for each sequence pair. Evolutionary analyses were conducted in MEGA6 (Tamura et al. 2013). The evolutionary history was inferred by using the Maximum Likelihood method based on the General Time Reversible model (Nei \& Kumar 2000). The tree with the highest log likelihood (-9133.8776) is shown (Fig. 1). The percentage of trees (based on 1000 replicates) in which the associated taxa clustered together is shown next to the branches. Initial tree(s) for the heuristic search were obtained automatically by applying NeighborJoin and BioNJ algorithms to a matrix of pairwise distances estimated using the Maximum Composite Likelihood (MCL) approach. The topology with a superior log likelihood value was selected. A discrete Gamma distribution was used to model evolutionary rate differences among sites $(5$ categories $(+G$, parameter $=0.566))$. The rate variation model allowed for some sites to be evolutionarily invariable $([+\mathrm{I}]$, $36.56 \%$ sites). The tree is drawn to scale, with branch lengths measured in the number of substitutions per site. The analysis included 34 nucleotide sequences. Codon positions included were $1^{\text {st }}+2^{\text {nd }}+3^{\text {rd }}$. All positions with less than $85 \%$ site coverage were eliminated. That is, fewer than $15 \%$ alignment gaps, missing data, and ambiguous bases were allowed at any position.

\section{Results}

\section{Tree description and genetic distances between species}

The gene tree might not be suitable for reconstructing deeper phylogenetic splits, but the order Sphaerotheriida and the family Zephroniidae were recovered as monophyletic taxa. Genetic distances were high, interspecific distances in our dataset of Zephroniidae varied between 13.6-24.4\% (Supp. file 1). The maximum likelihood tree based on the COI barcoding fragment showed low support (51\%) for the family Zephroniidae, with Cryxus in a basal position to a trichotomy (Fig. 1). Bootstrap support was generally low, with only a few species-groups, like the Zephronia 'sensu stricto' group encompassing $Z$. ovalis, Z. laotica, Z. dawydoffi and Z. siamensis, receiving high support values (Fig. 1). Most Sphaerobelum species grouped together, albeit with low support. Sphaerobelum aesculus Rosenmejer \& Wesener sp. nov. was retrieved in an isolated position and differed from the closest related species (Fig. 1), a Zephroniidae species (Zephroniidae_spII) of an unknown genus obtained from pet trade of Malaysia, 
Table 2. Genetically analysed specimens, voucher and GenBank number. Specimens marked by an * have been newly sequenced. Abbreviations: $M H N G=$ Muséum d'Histoire naturelle de la Ville de Genève, Geneva, Switzerland; NHMD = Natural History Museum of Denmark, University of Copenhagen; QVMAG = Queen Victoria Museum and Art Gallery, Tasmania, Australia; SMF = Senckenberg Museum Frankfurt, Germany; ZFMK = Zoological Research Museum Koenig, Bonn, Germany.

\begin{tabular}{|c|c|c|}
\hline Species & Voucher \# & GenBank \# \\
\hline Spirostreptida, Doratogonus sp. GG-2003 & unknown & AY288738 \\
\hline Spirobolida, Epibolus pulchripes & ZFMK MyrXX & MK330970 \\
\hline Glomerida, Glomeris marginata & ZFMK Myr009 & FJ409909 \\
\hline Sphaerotheriida, unknown family, Epicyliosoma sp. GB & unknown & AF370841 \\
\hline Sphaerotheriida, Procyliosomatidae, Procyliosoma leae & QVMAG 23:45801 & FJ409910 \\
\hline Sphaerotheriida, Procyliosomatidae, Procyliosoma sp. & QVMAG 23:25721 & FJ409911 \\
\hline Sphaerotheriida, Arthrosphaeridae, Arthrosphaera brandti & FMNH-INS 8650 & FJ409915 \\
\hline Sphaerotheriida, Zephroniidae sp. Ia & ZFMK Myr014 & FJ409912 \\
\hline Sphaerotheriida, Zephroniidae sp. Ib & ZFMK Myr015 & FJ409913 \\
\hline Sphaerotheriida, Zephroniidae sp. II (unknown genus) & lost & FJ409914 \\
\hline Sphaerotheriida, Zephroniidae, Sphaerobelum truncatum & FMNH-INS 72673 & JN885184 \\
\hline Sphaerotheriida, Zephroniidae, Zephronia siamensis & FMNH-INS-72669 & JX486067 \\
\hline Sphaerotheriida, Zephroniidae, Zephronia ovalis & ZFMK Myr0832 & JX486068 \\
\hline Sphaerotheriida, Zephroniidae, Cryxus ovalis & ZFMK Myr0824 & JX486069 \\
\hline Sphaerotheriida, Zephroniidae, Zephronia dawydoffi & ZFMK Myr4504 & MK330971 \\
\hline Sphaerotheriida, Zephroniidae, Zephronia laotica & ZFMK Myr3502 & MK330977 \\
\hline Sphaerotheriida, Zephroniidae, Sphaerobelum bolavensis & MHNG LT-10/24 & MK330982 \\
\hline Sphaerotheriida, Zephroniidae, Sphaerobelum phouloei & NHMD00040257 & MK330974 \\
\hline Sphaerotheriida, Zephroniidae, Sphaerobelum denticulatum & MHNG LT-10/12 & MK330983 \\
\hline Sphaerotheriida, Zephroniidae, Sphaerobelum spinatum & ZMUC00040258 & MK330973 \\
\hline Sphaerotheriida, Zephroniidae, Sphaerobelum lachneeis & MHNG LT-10/12 & MK330982 \\
\hline Sphaerotheriida, Zephroniidae, Sphaerobelum peterjaegeri & SMF SD553 & MK330972 \\
\hline Sphaerotheriida, Zephroniidae, Sphaerobelum nigrum & SMF & MK330976 \\
\hline Sphaerotheriida, Zephroniidae, Sphaerobelum laoticum & SMF & MK330975 \\
\hline Sphaerotheriida, Zephroniidae, Sphaerobelum schwendingeri & MHNG LT 10/03 & MK330978 \\
\hline Sphaerotheriida, Zephroniidae, Sphaerobelum schwendingeri & SMF & MK330981 \\
\hline Sphaerotheriida, Zephroniidae, Sphaerobelum sp. L07 & NHMD00040261 & MK330979 \\
\hline Sphaerotheriida, Zephroniidae, Sphaerobelum sp. L10 & SMF & MK330980 \\
\hline $\begin{array}{l}\text { Sphaerotheriida, Zephroniidae, } \\
\text { Sphaerobelum aesculus Rosenmejer \& Wesener sp. nov., holotype, ठૈ* }\end{array}$ & NHMD 621693 & MW898737 \\
\hline $\begin{array}{l}\text { Sphaerotheriida, Zephroniidae, } \\
\text { Sphaerobelum aesculus Rosenmejer \& Wesener sp. nov., }, *\end{array}$ & NHMD 621694 & MW898738 \\
\hline Sphaerotheriida, Zephroniidae, Zephronia sp., AowNoiTemple* & NHMD K45 & MW898741 \\
\hline Sphaerotheriida, Zephroniidae, Zephronia sp., AowNoiTemple* & ZFMK MYR8822 & MW898742 \\
\hline $\begin{array}{l}\text { Sphaerotheriida, Zephroniidae, } \\
\text { Zephronia viridisoma Rosenmejer \& Wesener sp. nov., holotype, đే* }\end{array}$ & NHMD 621695 & MW898739 \\
\hline $\begin{array}{l}\text { Sphaerotheriida, Zephroniidae, } \\
\text { Zephronia viridisoma Rosenmejer \& Wesener sp. nov., paratype, }, *\end{array}$ & ZFMK MYR8787 & MW898740 \\
\hline
\end{tabular}


by $17.9 \%$ (Supp. file 1). The two specimens of S. aesculus sp. nov., found $160 \mathrm{~km}$ apart (Fig. 2), differed by $6.1 \%$. Holotype and paratype of Zephronia viridisoma sp. nov. showed no intraspecific distance and differed by $16.7 \%$ from the genetically closest taxon, an undescribed Zephronia from Aow Noi Temple (Mueang district, Prachuap Khiri Khan Province).

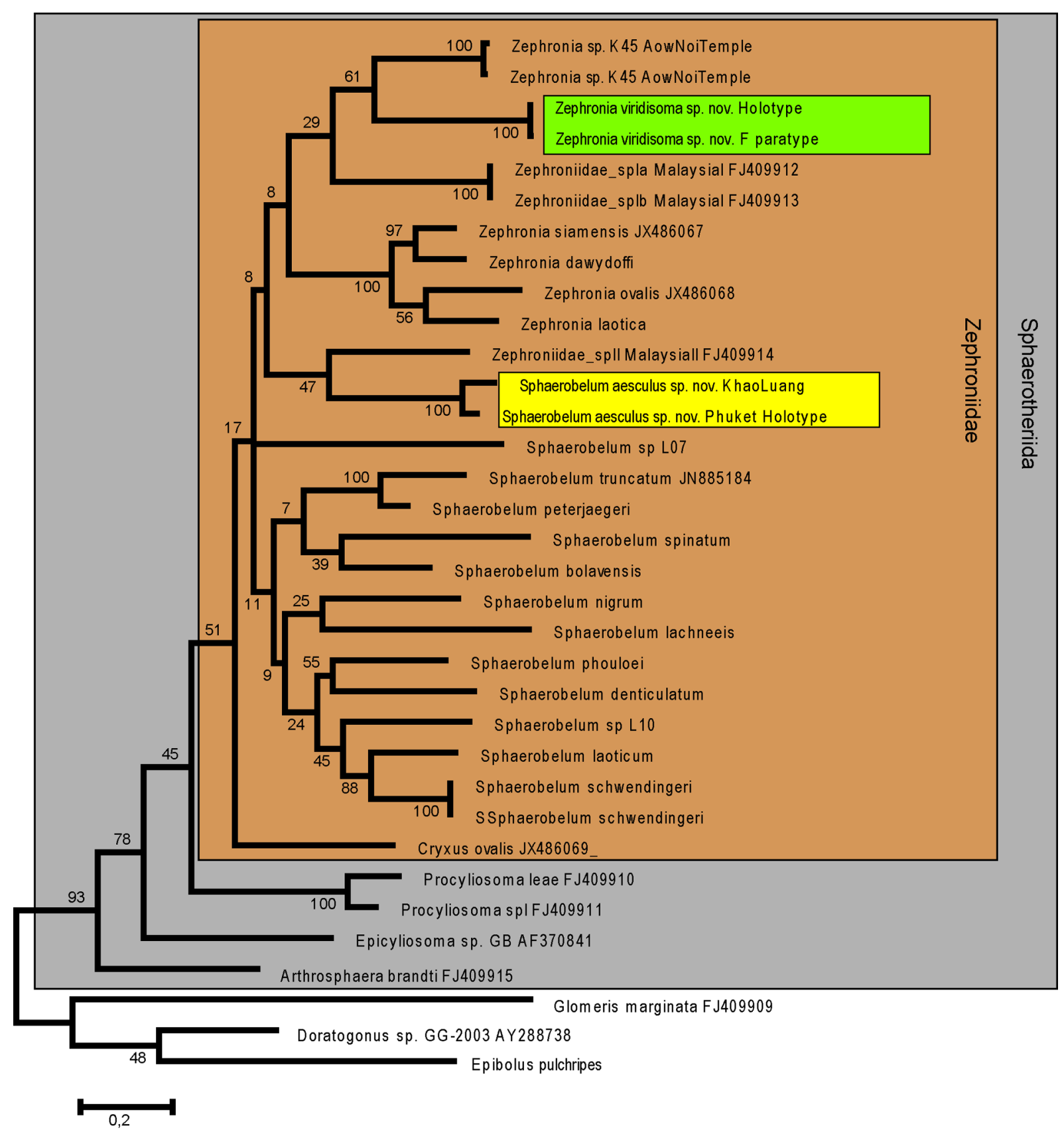

Fig. 1. The evolutionary history of the analyzed Sphaerotheriida Brandt, 1833 inferred by using the Maximum Likelihood method analyzed with the General Time Reversible model based on the COI gene. The tree is drawn to scale, with branch lengths measured in the number of substitutions per site. Codon positions included were $1^{\text {st }}+2^{\text {nd }}+3^{\text {rd }}$. All positions with less than $5 \%$ site coverage were eliminated. Yellow and green boxes mark the newly described species. Numbers below branches mark bootstrap values (1000 replicates). For specimen information see Table 2. 
Taxonomy

Class Diplopoda de Blainville in Gervais, 1844

Order Sphaerotheriida Brandt, 1833

\section{Remarks}

Family Zephroniidae Gray, 1843

See Wesener (2016a) for a catalogue of the family.

Genus Sphaerobelum Verhoeff, 1924

\section{Type species}

Sphaerobelum clavigerum Verhoeff, 1924, from Vietnam.

\section{Other taxa included}

18 species including the one described below (Semenyuk et al. 2018, 2020; Wesener 2019; Zhao et al. 2020).

\section{Distribution}

Vietnam, Thailand, Laos, China.

Sphaerobelum aesculus Rosenmejer \& Wesener sp. nov. urn:1sid:zoobank.org:act:84D3714E-5CF8-4063-8A4D-40BF8CBEBFB0

Figs $2 \mathrm{~A}, 3-5,6 \mathrm{~A}$

\section{Diagnosis}

Differs from all other species of the genus Sphaerobelum in the shape of the posterior telopod, where there is a swelling at the tip of the immovable finger, but the swelling does not extend above the margin (Fig. 5B arrow). Such a swelling is currently unknown from any other giant pill-millipede species.

\section{Derivatio nominis}

Named after the horse chestnut tree Aesculus hippocastanum L., for the resemblance of the rolled-up female to a horse chestnut. Noun in apposition.

\section{Material examined}

\section{Holotype}

THAILAND • đ’; Phuket Island, Forest in Kathu district; 14 Feb.1989. M. Andersen and A.R. Rasmussen leg.; in and under old logs; NHMD 621693.

\section{Other material}

THAILAND • 1 \%; Nakhon Si Thammarat Prov., Khao Luang NP; 843'25.2" N, 9940'7.7" E, 355 m a.s.1.; 10-12 Oct. 2003; ATOL Expedition 2003 leg.; NHMD 621694.

Description (based on holotype)

SizE. Length $23.8 \mathrm{~mm}$. Width of thoracic shield $10.5 \mathrm{~mm}$, of widest segment (9) $11.1 \mathrm{~mm}$. Height of thoracic shield $6.2 \mathrm{~mm}$, Height of highest segment (7) $7 \mathrm{~mm}$.

Colour. Head, antenna, legs and tergites golden light brown. Posterior margin of tergites and paratergite tips medium brown. Anal shield medially brown, with lighter colour at edges (Fig. 2A). 


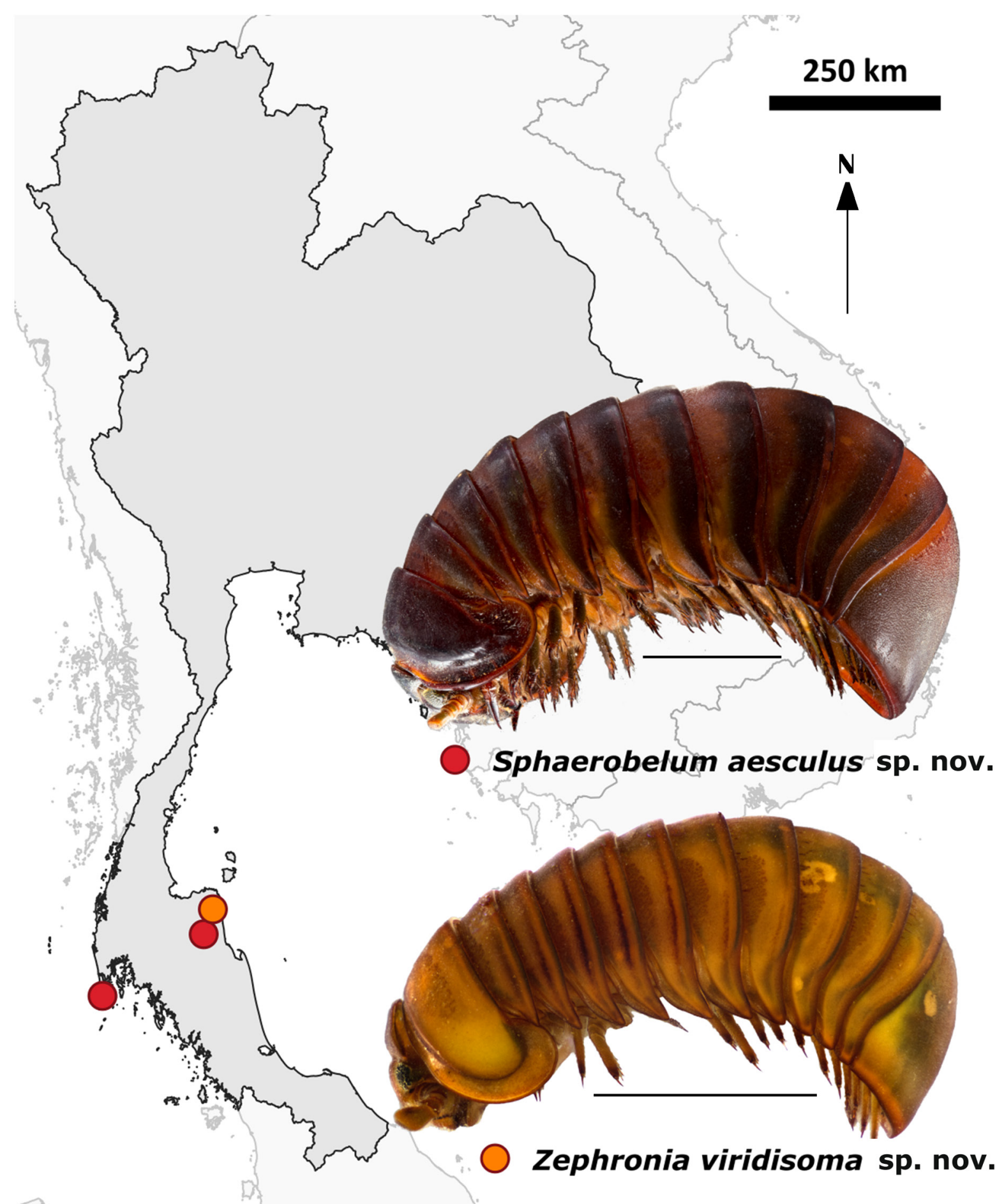

Fig. 2. Map of Thailand, collection localities of Sphaerobelum aesculus Rosenmejer \& Wesener sp. nov. and Zephronia viridisoma Rosenmejer \& Wesener sp. nov., and habitus photographs: S. aesculus Rosenmejer \& Wesener sp. nov., + (NHMD 621694); Z. viridisoma Rosenmejer \& Wesener sp. nov., paratype, $q$ (ZFMK MYR8787). Scale bars $=1 \mathrm{~cm}$. 
HEAD. Number of ommatidia 55. Antennae (Fig. $3 A-C$ ): Antennomere lengths: $6>1>2=3=4=5$. Antennae short, barely reaching first leg pair. Sixth antennomere apically slightly swollen (Fig. 3A), number of apical cones 52/56 (Fig. 3B). Mandible: not dissected. Gnathochilarium: lingual lamella with numerous long setae, medially glabrous.

Collum. With few setae spread thinly along borders.

THORACIC SHIELD. Thoracic shield grooves wide and deep, with 3 sclerotized ledges along inner ridge.

TERGITES. Paratergite tips on posterior half projecting backwards. Tergites glabrous with dull leather-like surface (Fig. 3D-E). At high magnification tiny setae become visible.

ENDOTERGUM (Fig. 6A). With a regular flat margin. Outer zone with two rows of irregular

MARGINAL SETAE. Not extending beyond posterior margin, but reaching $2 / 3$ of the outer area. Anterior part of marginal ridge flat. Intersegmental membrane smooth, without cones and with a row of setae with large glabrous gaps.

First STIGMATIC PLATE (Fig. 4A). With a well-rounded apex.

PleuRItes. Pleurite 1 projecting posteriorly with sharp apex. Pleurite 2 with rounded apex projecting slightly.

Legs. Ventral spines on leg $14 / 4$, on leg $23 / 5$, on leg $33 / 4$. Apical spine absent on leg 3 . Three apical and 4 or 5 ventral spines on midbody legs (Fig. 4C). Inner margin of femur with 8-12 small teeth, but not excavated. Femur 2, tarsus 4 times as long as wide.

ANAL SHIELD. Well-rounded and glabrous. Ventral side with a single small locking carina, placed $1 / 3$ from pleurite.

MALE GONOPORE. Located at mesal margin of coxa (Fig. 4B), large, covered by a membranous plate.

ANTERIOR TELOPODS (Fig. 4D-F). Podomere 1 rectangular, as long as wide, covered with setae anteriorly, with extra long setae medially, and posteriorly glabrous. Podomere 2 with long immovable finger visible laterally in anterior view. Finger curving inwards against podomere 3. Podomere 3 cylindrical twice as long as wide. Suture between podomere 3 and 4 barely visible in posterior and lateral views. Podomere 4 very short, just $1 / 4$ of length of podomere 3 , with one short and dark spine on apex.

Posterior telopods (Fig. 5A-B). Podomere 1 as long as wide, covered in setae anteriorly, and nearly glabrous posteriorly. Podomere 2 with wide immovable finger. Immovable finger straight, only slightly tapering towards apex, bearing an oval membranous spot on posterior side. The membrane between podomere 2 and 3 with single membranous lobe, angled. Podomere 3 with sparse setation. Podomere 3 ca 3 times longer than wide, towards immovable finger with membranous ledge, a single spine, posterior side with row of 9 or 10 crenulated teeth. Podomere 4 short, straight, ca 2.5 times as long as wide, with a short membranous ledge and 2 spines towards immovable finger.

\section{Female from Khao Luang NP}

Length $45 \mathrm{~mm}$. Width of thoracic shield $23 \mathrm{~mm}$, of widest segment (9) $24.6 \mathrm{~mm}$. Height of thoracic shield $12.6 \mathrm{~mm}$, of highest segment (8) $15.2 \mathrm{~mm}$. Antennae reaching leg pair 2. Apical cones on antennae 43/34. Subanal plate well rounded. Vulvae (Fig. 5C): small, with a narrow operculum (Op), only reaching bottom part of prefemur. External lateral plate (EP) and inner mesal plate (IP) almost completely fused. 

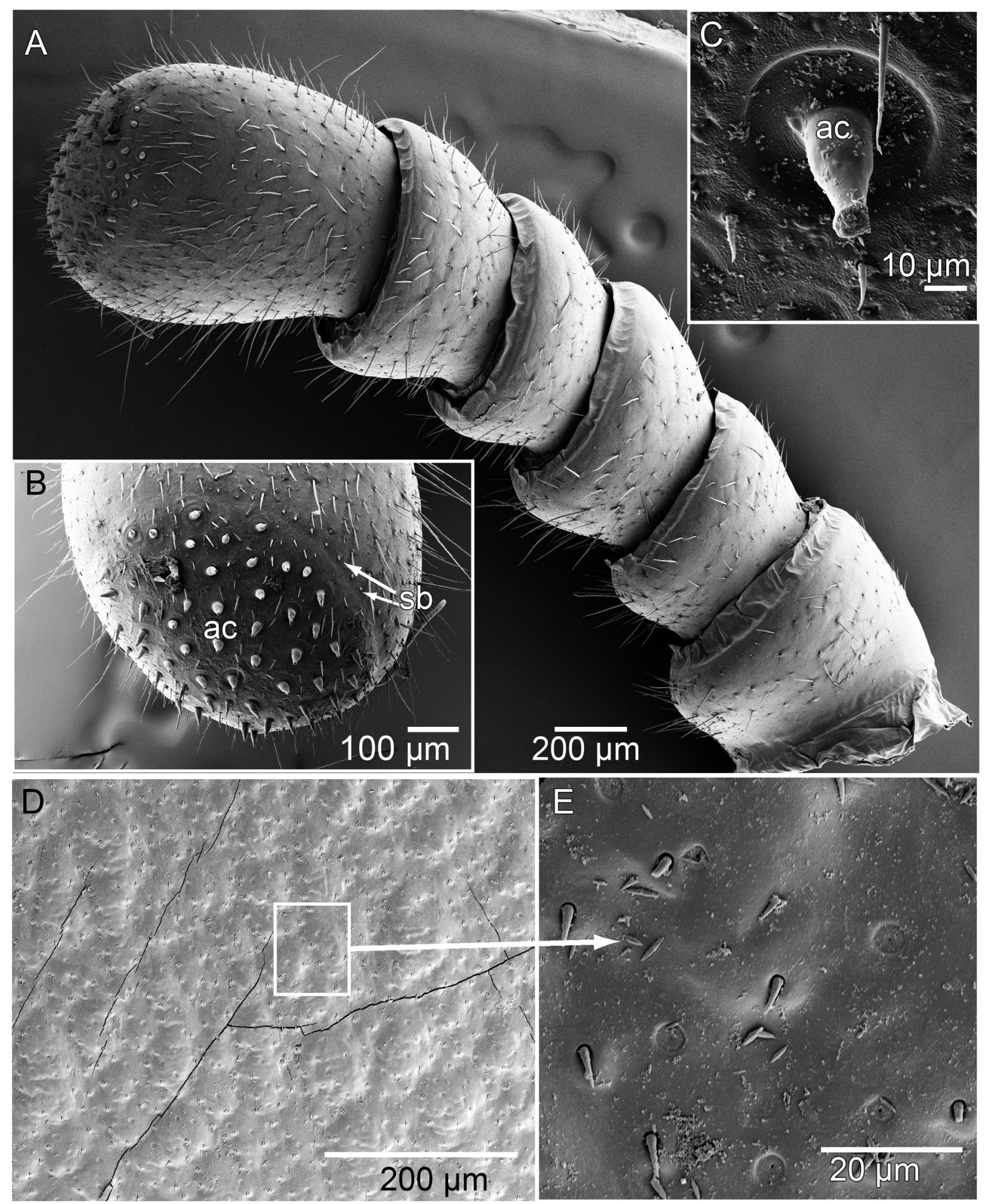

Fig. 3. Sphaerobelum aesculus Rosenmejer \& Wesener sp. nov., holotype, $\widehat{\partial}$ (NHMD 621693), scanning electron micrographs. A. Right antenna, lateral view. B. Right antenna, disc. C. Detail of apical cone. D. Tergite surface of midbody ring. E. Tergite surface at very high magnification. Abbreviations: ac $=$ apical cone; $\mathrm{sb}=$ sensilla basiconica. 


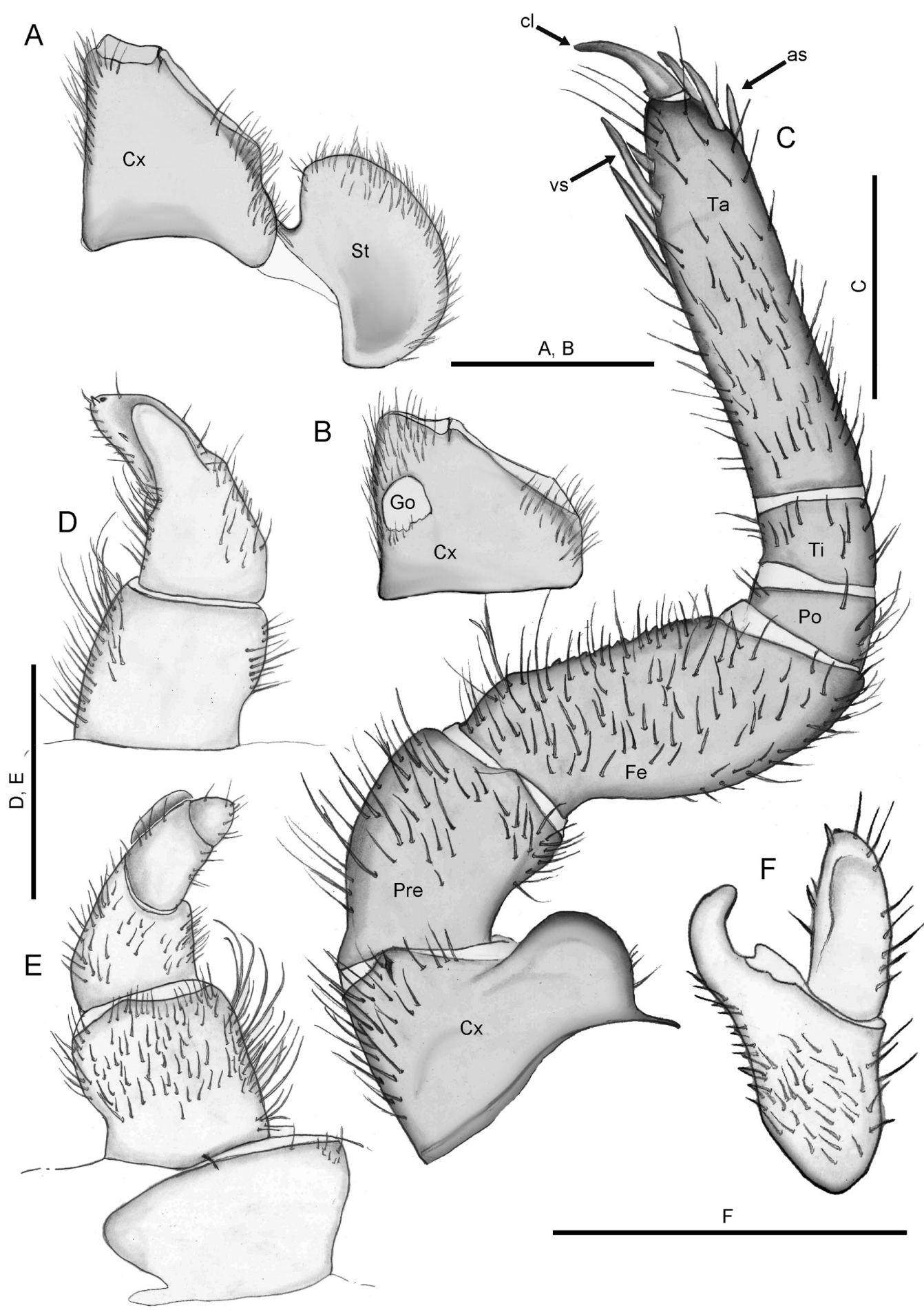

Fig. 4. Sphaerobelum aesculus Rosenmejer \& Wesener sp. nov., holotype, §̊ (NHMD 621693), drawings. A. First left coxa with stigmatic plate, posterior view. B. Second left coxa with gonopore, posterior view. C. Left leg 9, posterior view. D. Left anterior telopod, posterior view. E. Left anterior telopod, anterior view. F. Left anterior telopod, lateral view on podomeres $2-4$. Abbreviations: as $=$ apical spine; $\mathrm{cl}=$ claw; $\mathrm{Cx}=$ coxa; $\mathrm{Fe}=$ femur; $\mathrm{Go}=$ gonopore; $\mathrm{Po}=$ postfemur; $\mathrm{Pre}=$ prefemur; $\mathrm{St}=$ stigmatic plate; $\mathrm{Ta}=$ tarsus; $\mathrm{Ti}=$ tibia; $\mathrm{vs}=$ ventral spines. Scale bars $=1 \mathrm{~mm}$. 


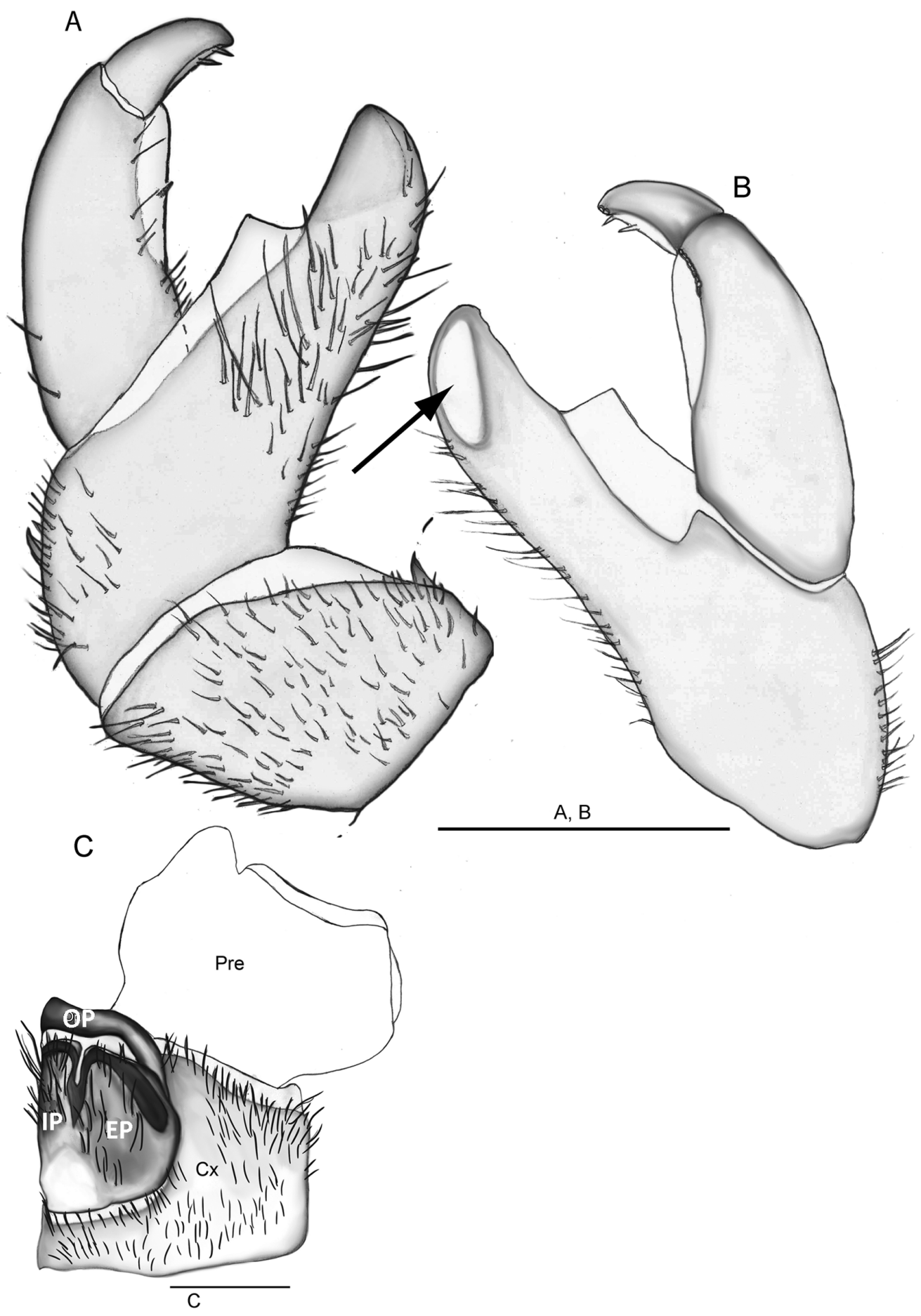

Fig. 5. Sphaerobelum aesculus Rosenmejer \& Wesener sp. nov. drawings. A-B. Holotype, ô (NHMD 621693), C. \& (NHMD 621694). A. Left posterior telopod, anterior view. B. Left posterior telopod, posterior view, arrow points to swelling of immovable finger. C. Left second coxa and prefemur with female vulva. Abbreviations: $\mathrm{Cx}=$ coxa; $\mathrm{EP}=$ external, lateral plate; $\mathrm{IP}=$ inner, mesal plate; $\mathrm{Op}=$ operculum; Pre = prefemur. Scale bars $=1 \mathrm{~mm}$. 


\section{Distribution}

If the female from Khao Luang (Fig. 2A) is indeed conspecific with the male holotype, the species appears to have a wide area of distribution stretching from Phuket Island at least $160 \mathrm{~km}$ to the east (Fig. 2). Unpublished data from a larger inventory project (see, e.g., Wesener et al. 2021) of giant pill-millipedes in the surroundings of Krabi, half way between Phuket Island and Khao Luang, did not recover this species among the numerous specimens, hinting at a patchy distribution and specific microhabitat requirements of $S$. aesculus sp. nov.

\section{Genus Zephronia Gray, 1832}

\section{Type species}

Zephronia ovalis Gray, 1832.

\section{Other taxa included}

44 species, including the one described below (Wesener 2016a, 2019; Semenyuk et al. 2018, 2020).

\section{Distribution}

NE India, Nepal, Myanmar, with a few species also in SE Asia.

\section{Remark}

Likhitrakarn et al. (2021) provided an updated diagnosis of this genus including the presence of several apical tarsal spines. The new species described here necessitates a slight modification, as it has only one apical tarsal spine.
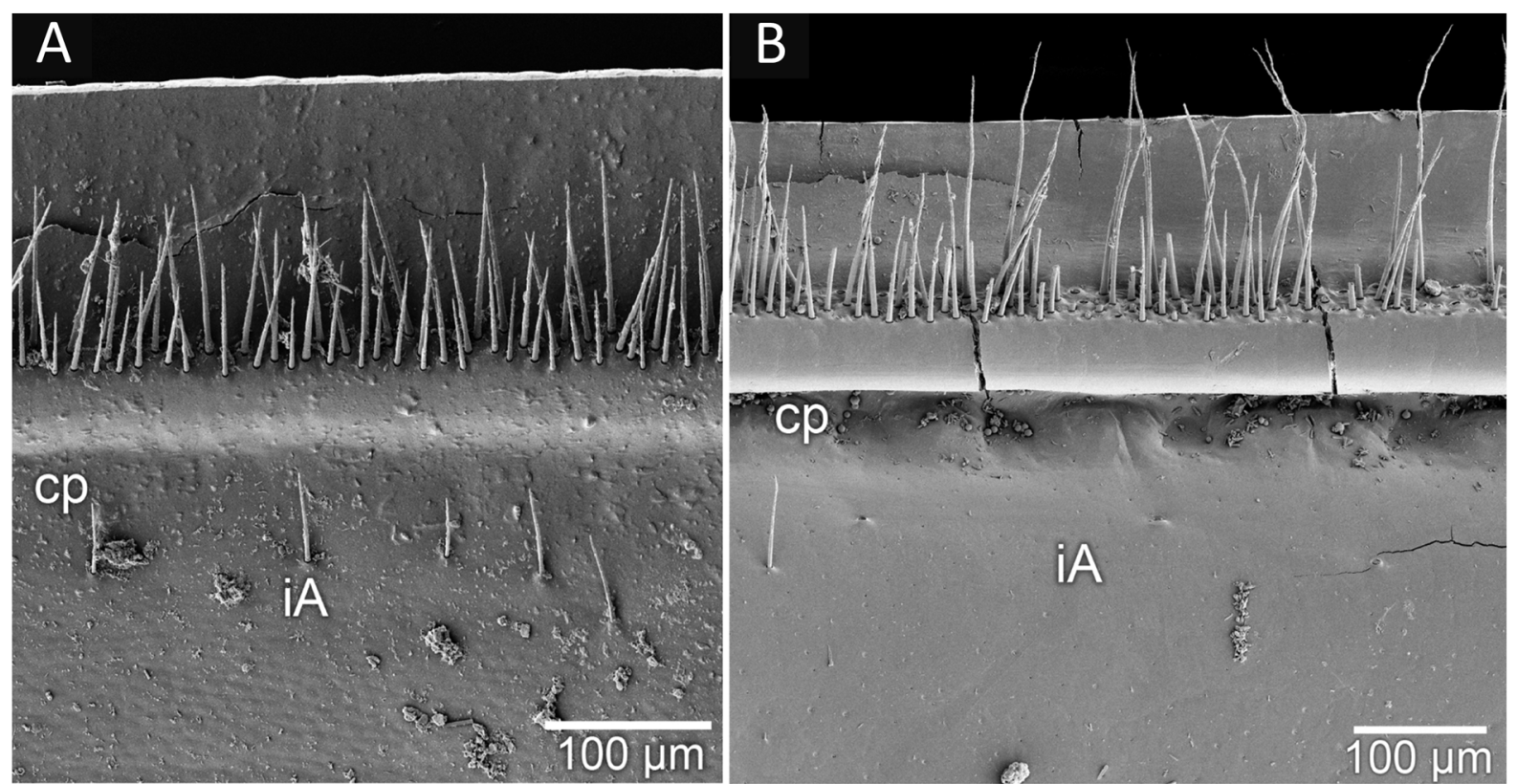

Fig. 6. Endoterga of midbody tergites, scanning electron micrographs. A. Sphaerobelum aesculus Rosenmejer \& Wesener sp. nov., holotype (NHMD 621693). B. Zephronia viridisoma Rosenmejer \& Wesener sp. nov., holotype, $\widehat{\partial}$ (NHMD 621695). Abbreviations: $\mathrm{cp}=$ cuticular patterns; iA = inner area. 
Zephronia viridisoma Rosenmejer \& Wesener sp. nov. urn:Isid:zoobank.org:act:272E06C8-2DE5-4722-A7D5-D85002D68424

Figs $2 \mathrm{~B}, 6 \mathrm{~B}-12$

\section{Diagnosis}

Posterior telopod typical for the genus, not differing from those of other Zephronia species. Small (25$28 \mathrm{~mm}$ long) green species (Fig. 2B), surface appearing glabrous, dull, with a single medium sized locking carina at the anal shield and a strongly projecting pleurite 1 (Fig. 9A). One of the few Zephronia species with just a single apical spine on the legs (Fig. 9B), differing in this character from all other described Thai Zephronia species which have 2-5 apical tarsal spines. Male antennomere 6 swollen (Fig. 7A) but not axe-shaped, with $<50$ apical cones. Endotergum with three dense rows of long marginal setae (Fig. 6B). Palpi of gnathochilarium with sensory cones arranged in clusters (Fig. 8C-D). Anterior telopod podomere 3 with an elevated process at posterior side carrying sclerotized teeth. Podomere 4 short and narrow.

\section{Derivatio nominis}

Named after the overall green colour of living individuals of the species, noun in apposition.

\section{Material examined}

\section{Holotype}

THAILAND - đ'; Nakhon Si Thammarat Province, Sichon District, Khao Lark Waterfall; $9^{\circ} 03^{\prime} 6^{\prime \prime} \mathrm{N}$, 9947'24" E; 25 Aug. 2007; Chulalongkorn University expedition of millipede workshop leg.; dense jungle on limestone; NHMD 621695.

\section{Paratypes}

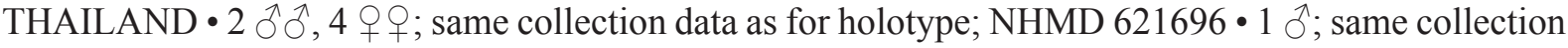
data as for holotype; ZFMK MYR8786・1 ; ; same collection data as for holotype; CT scan voucher; ZFMK MYR8787.

Description (based on holotype)

SIzE. Length $25.6 \mathrm{~mm}$. Width of thoracic shield $12.1 \mathrm{~mm}$, of widest segment (8) $13 \mathrm{~mm}$. Height of thoracic shield $7.1 \mathrm{~mm}$, of highest segment (8) $7.7 \mathrm{~mm}$.

Colour. Head medium brown, faded from green. Antennae medium brown. Legs medium brown, tarsal claws apically dark brown. Tergites light brown, faded green medially, with darker brown posterior margin. Paratergite tips medium brown with darker edges. Anal shield dark green, edges faded to brown (Fig. 2B).

HeAD (Fig. 7A-C). Number of ommatidia 50 (Fig. 7B). Organ of Tömösváry placed midway between ocelli and antennal groove (Fig. 7A), with its typical coral-like inner structure (Fig. 7C).

Antennae (Fig. 7A, D). Reaching leg pair 3, 6 visible antennomeres. Antennomere lengths: $6>1>2=3>4=5$. Antennomere 6 apically swollen, number of apical cones 32/44.

EPIPHARYNX (Fig. 8A). With an extraordinarily large inner tooth.

Mandible (Fig. 8E-F). Inner tooth 3-cusped. Pectinate lamellae with 6 or 7 rows of teeth. Condylus at anterior margin with two ridges. 


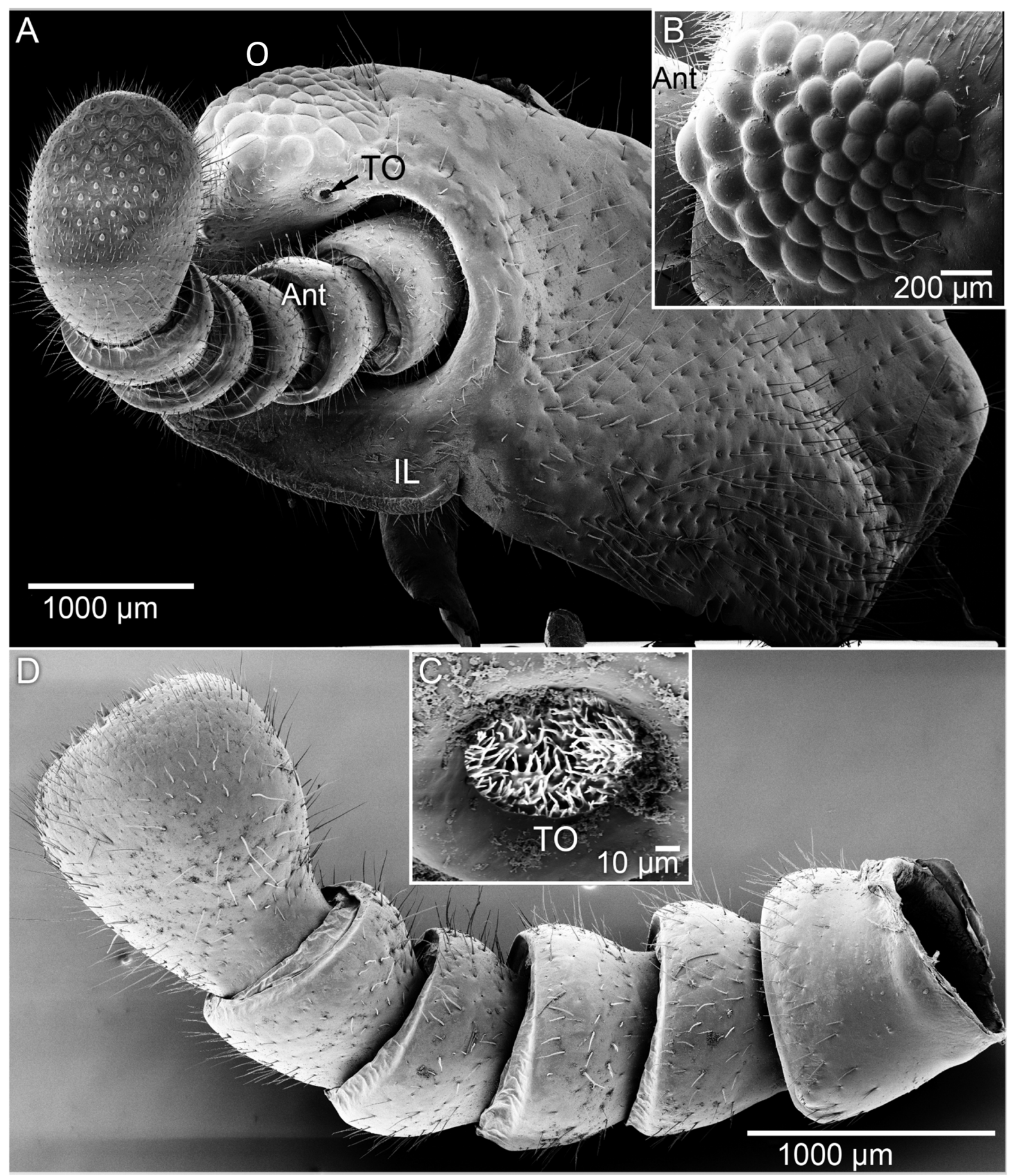

Fig. 7. Zephronia viridisoma Rosenmejer \& Wesener sp. nov., paratype, § (ZFMK MYR8786), head, scanning elelctron micrographs. A. Lateral view. B. Right eye. C. Organ of Tömösváry. D. Left antenna, lateral view. Abbreviations: $A n t=$ antenna; $\mathrm{IL}=$ incisura lateralis; $\mathrm{O}=$ ommatidia; $\mathrm{TO}=$ organ of Tömösváry. 


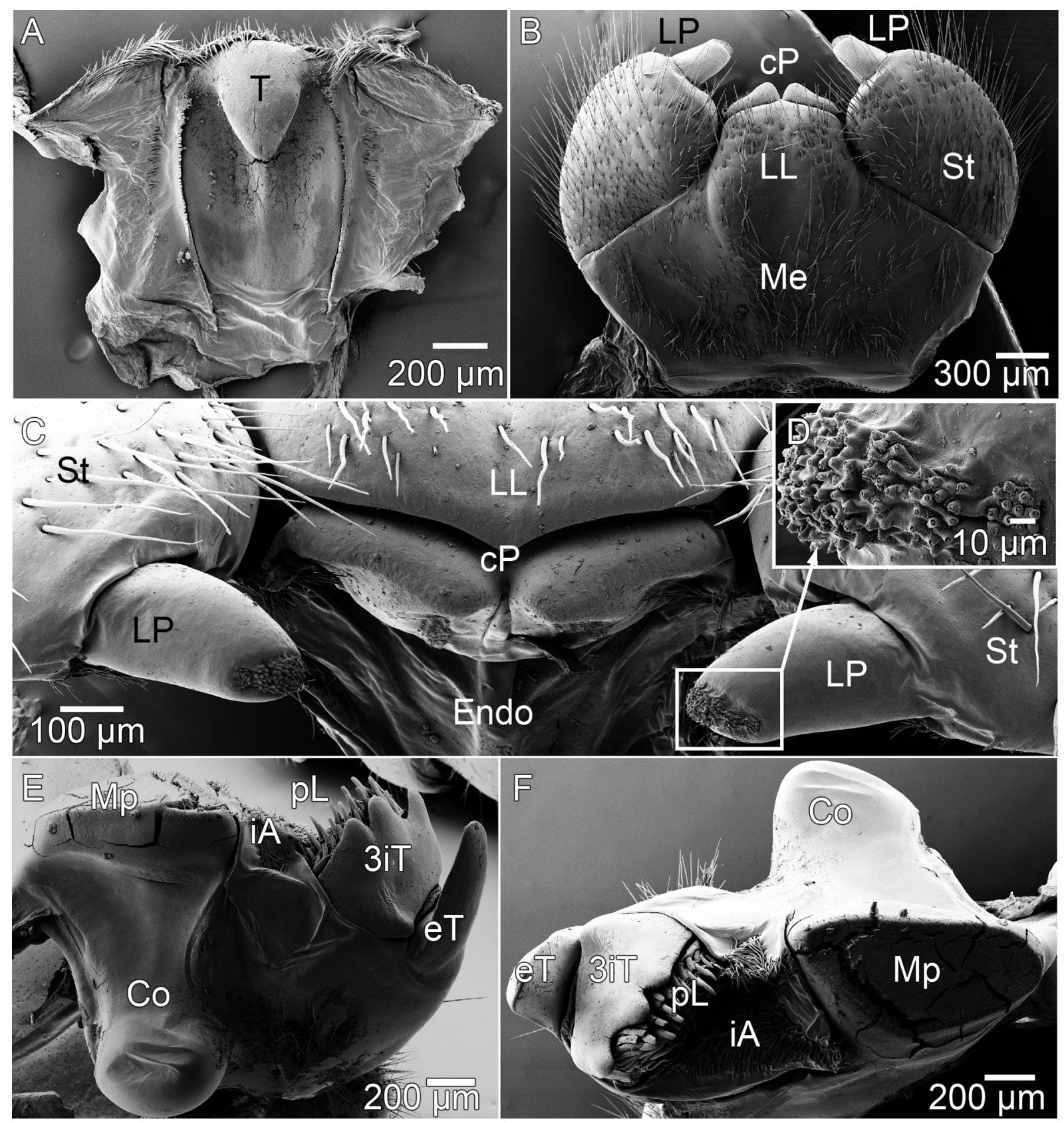

Fig. 8. Zephronia viridisoma Rosenmejer \& Wesener sp. nov., paratype, ô (ZFMK MYR8786), mouthparts, scanning electron micrographs. A. Epipharynx, ventral view. B. Gnathochilarium, underside. C. Gnathochilarium frontal view at lateral palps and central pads. D. Detail of sensory cones at lateral palps. E. Right mandible, dorsal view. F. Right mandible, mesal view. Abbreviations: $3 \mathrm{iT}=3$-combed inner tooth; $\mathrm{Co}=$ condylus; $\mathrm{cP}=$ central pads; $\mathrm{Endo}=$ endochilarium; $\mathrm{eT}=$ external tooth; $\mathrm{iA}=$ inner area; $\mathrm{LL}=$ lamellae linguales; $\mathrm{LP}=$ lateral palpi; $\mathrm{Me}=$ mentum; $\mathrm{Mp}=$ molar plate; $\mathrm{pL}=$ pectinate lamellae; $\mathrm{St}=$ stipes; $\mathrm{T}=$ tooth of epipharynx. 


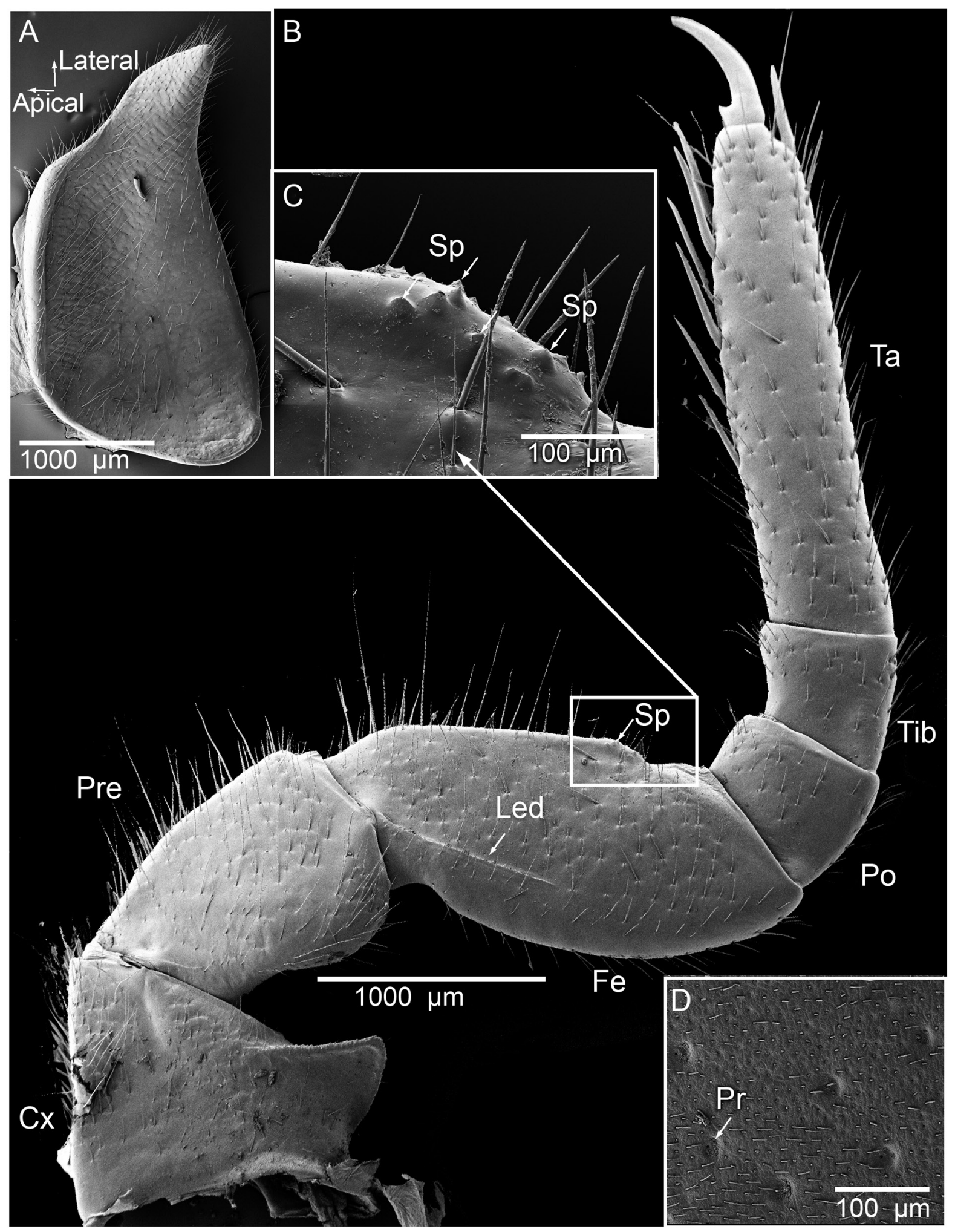

Fig. 9. Zephronia viridisoma Rosenmejer \& Wesener sp. nov., paratype, ồ (ZFMK MYR8786), legs and pleurite (laterotergite), scanning electron micrographs. A. First pleurite. B. Left midbody leg, posterior view. C. Leg, femur, detail of sclerotized teeth. D. Surface of midbody tergite. Abbreviations: $\mathrm{Cx}=$ $\operatorname{coxa} ; \mathrm{Fe}=$ femur; $\mathrm{Led}=$ ledge $; \mathrm{Po}=$ postfemur; $\mathrm{Pr}=$ protuberance; $\mathrm{Pre}=$ prefemur $; \mathrm{Sp}=$ small triangular spines; $\mathrm{Ta}=$ tarsus; $\mathrm{Tib}=$ tibia. 
GnathochiLARIUm (Fig. 8B-D). Lamellae linguales with numerous long setae, medially glabrous. Stipes and mentum with numerous long setae in a regular patter. Sensory cones on gnathochilarium palps in clusters (Fig. 8D).

CoLLum. With short setation, evenly distributed across surface.

THORACIC SHIELD. Thoracic shield grooves wide and deep, with 9 sclerotized ledges along inner ridge of grooves.

TERgites (Fig. 9D). Tergites glabrous, with dull orange skin like surface. At high magnification tiny setae and knobs become visible. Paratergite tips on posterior half projecting backwards (Fig. 12A-B).

Endotergum (Fig. 6B). With a regular flat margin. Outer zone with three dense rows of irregular marginal setae, some of them extending beyond posterior margin. A single row of rounded cuticular impressions present next to marginal ridge. Intersegmental membrane smooth, without cones and with very few setae.

Stigmatic Plate (Fig. 10A). First plate with a rounded sub-triangular apex. More posterior plates similar to those of other representatives of the family, half-covered by the pleurites (Fig. 12C).

Pleurites (Figs 9A, 12D). Pleurite 1 projecting strongly, with sharp apex. Pleurite 2 projecting slightly less than 1 and with more rounded apex (Fig. 12D). Projection absent from pleurite 3 (Fig. 12D).

LEGs. Ventral spines on leg $11 / 1$, on leg $23 / 2$, on leg $34 / 4$. Apical spine on leg 3 absent. A single apical spine and 5 or 6 ventral spines on midbody legs (Fig. 9B). Femur regularly shaped, 2.2 times longer than wide, sclerotized ledge of medium length, inner margin apically with 5 or 6 small rounded triangular spines on ventral side (Fig. 9B-C). Tarsus 4.2 times longer than wide.

ANAL SHIELD. Well-rounded and glabrous. Ventral side with dark coloured. A medium-sized locking carina placed slightly closer to pleurite than margin (Fig. 12D).

MALE GONOPORE (Fig. 10B). Inconspicuous, consisting of large membranous opening located directly at mesal margin.

ANTERIOR TELOPODS (Fig. 10C-E). With long setae medially on the first 2 podomeres, covering posterior part on podomere 2. Podomere 1 rectangular, as long as wide. Podomere 2 in anterior view as wide as but slightly narrower than podomere 1. Immovable finger barely visible in anterior view (Fig. 10D), short, not protruding up to podomere 4 (Fig. 10C). Podomere 3 long and wide, with rounded projection on posterior side, bearing 3 crenulated teeth. Podomere 4 very narrow and short, with 3 large spines near apex, and a smaller spine near edge to podomere 3 .

Posterior telopods (Fig. 10F-G). Podomere 2 setose, immovable finger straight, apically tapering, with rows of small circular sclerotized spots. Membranous lobe between podomere 3 and 4 bearing 2 elongated processes, fused at base. Podomere 3 with 8 or 9 small crenulated teeth on posterior side. Membranous lobe on podomere 3 with single spine. Podomere 4 slightly curved towards immovable finger, membranous lobe with 2 spines. Setation on podomere 2 primarily on anterior side.

\section{Description of female paratype}

Length $25.6 \mathrm{~mm}$. Width of thoracic shield $12.3 \mathrm{~mm}$, of widest tergite (8) $13.7 \mathrm{~mm}$. Height of thoracic shield: $8.4 \mathrm{~mm}$, of highest tergite (8) $9.3 \mathrm{~mm}$. Antennae reaching leg pair 3. Apical cones left/right: 


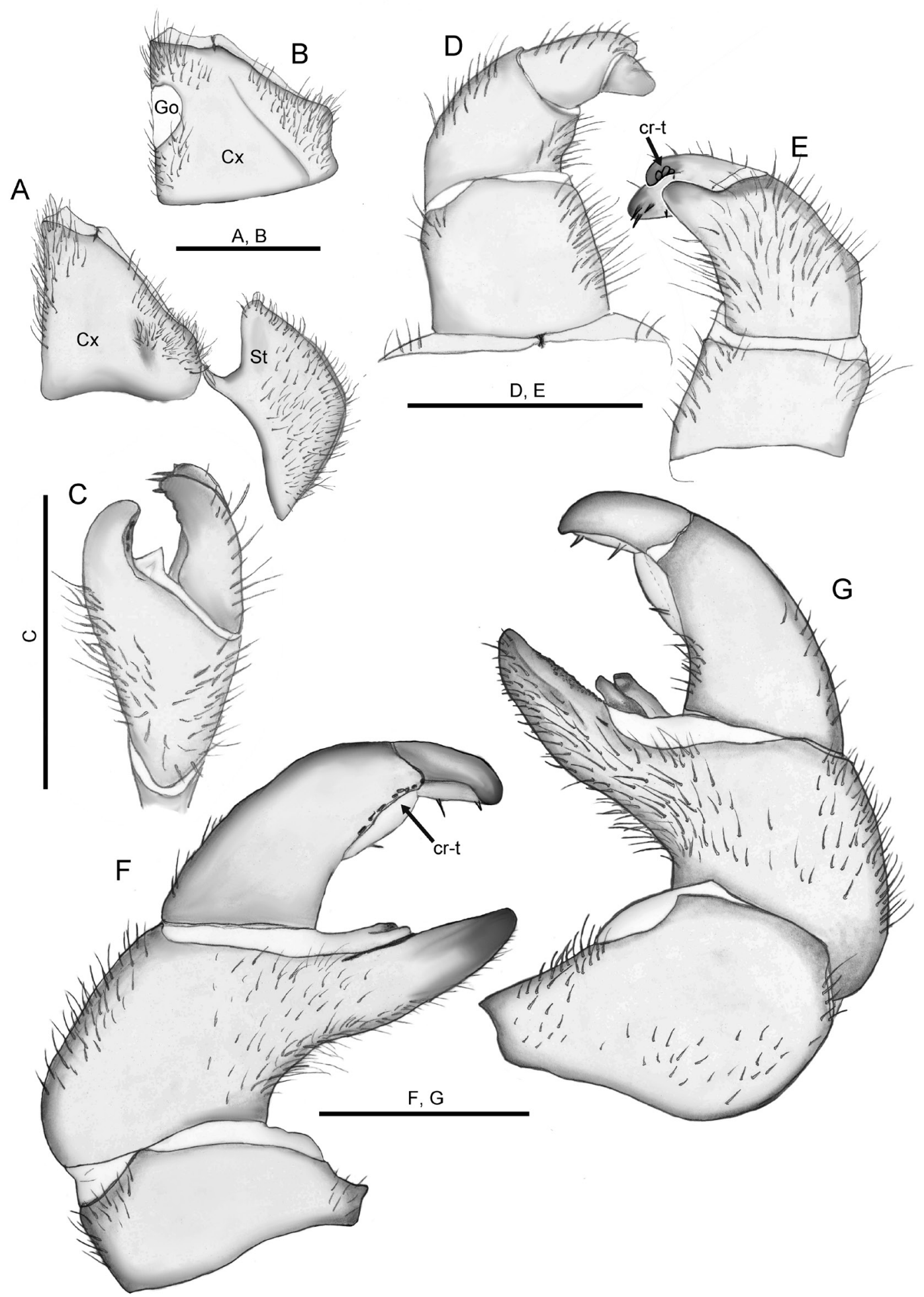

Fig. 10. Zephronia viridisoma Rosenmejer \& Wesener sp. nov., holotype, ô (NHMD 621695), drawings. A. Coxa of first left leg with stigmatic plate, posterior view. B. Coxa of second left leg with gonopore, posterior view. C. Left anterior telopod, lateral view on podomeres 2-4. D. Left anterior telopod, anterior view. E. Left anterior telopod, posterior view. F. Right posterior telopod, posterior view. G. Right posteiror telopod, anterior view. Abbreviations: $\mathrm{cr}-\mathrm{t}=$ crenulated teeth; $\mathrm{Cx}=\operatorname{coxa} ; \mathrm{Go}=$ gonopore; $\mathrm{St}=$ stigmatic plate. Scale bars $=1 \mathrm{~mm}$. 
25/25. Subanal plate well rounded. Vulvae (Fig. 11): with a large pointed operculum (Op). External lateral plate (EP) and inner mesal plate (IP) fused at bottom.

Another female paratype was used for microcomputed tomography. The resulting volume rendering is shown in Fig. 12. While this approach revaled no significant additional details it serves to illustrate morphology of the specimen in an excellent way, much better than any photograph.

\section{Discussion}

\section{Identity and biogeography of the genus Sphaerobelum}

Sphaerobelum aesculus sp. nov. is only tentatively placed in the genus Sphaerobelum as it differs in some characters from the other species of the genus. The immovable finger of the posterior telopod in $S$. aesculus sp. nov. is only weakly swollen, and the swelling is not projecting above the telopod margins (Fig. 5B) in contrast to all other species of Sphaerobelum (see Wongthamwanich et al. 2012). Sphaerobelum aesculus sp. nov. represents the southern-most known occurrence for the genus, with other species of Sphaerobelum having been collected at least $1000 \mathrm{~km}$ further north. Sphaerobelum aesculus

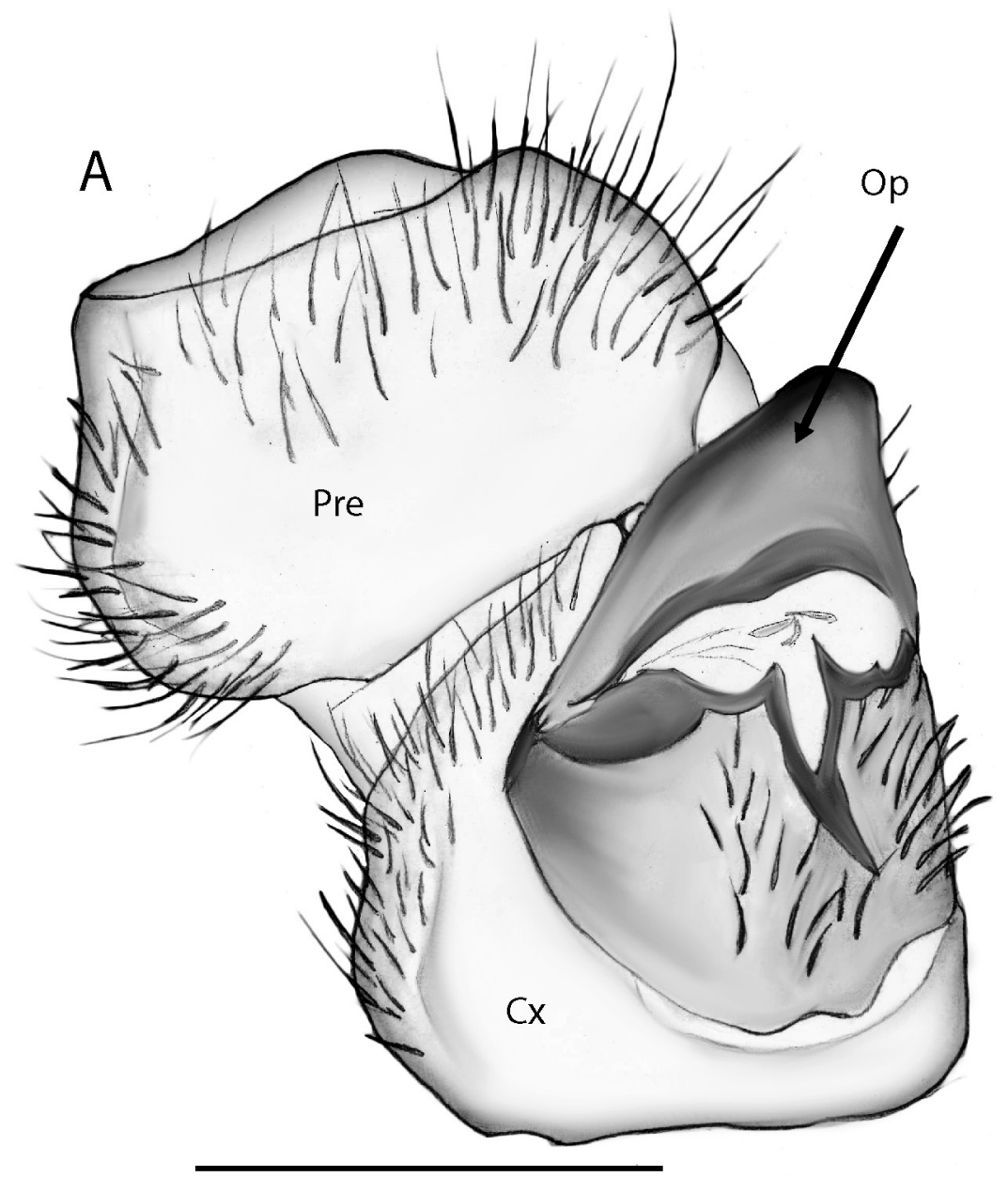

Fig. 11. Zephronia viridisoma Rosenmejer \& Wesener sp. nov., paratype, + (NHM D621696), drawings. A. Second right coxa and prefemur with vulva, posterior view. Abbreviations: $\mathrm{Cx}=$ coxa; Op $=$ operculum; Pre = prefemur. Scale bar $=1 \mathrm{~mm}$. 
sp. nov. differs clearly from the giant pill-millipede genera occurring further south, Tigridosphaera Jeekel, 2000, Sphaeropoeus Brandt, 1833 and Castanotherium Pocock, 1895. Sphaerobelum aesculus sp. nov. differs clearly from all known Castanotherium species in which the posterior telopod only consists of three joints, not four as in the new species described here. Sphaerobelum aesculus sp. nov. differs from Sphaeropoeus (see Wesener 2016b) as well as Tigridosphaera (see Jeekel 2000; Enghoff et al. 2015; Wesener 2016a) in details of the anterior telopod. In Tigridosphaera the last podomere of the anterior telopod is extending backwards producing a sharp process (very similar to the species of Prionobelum
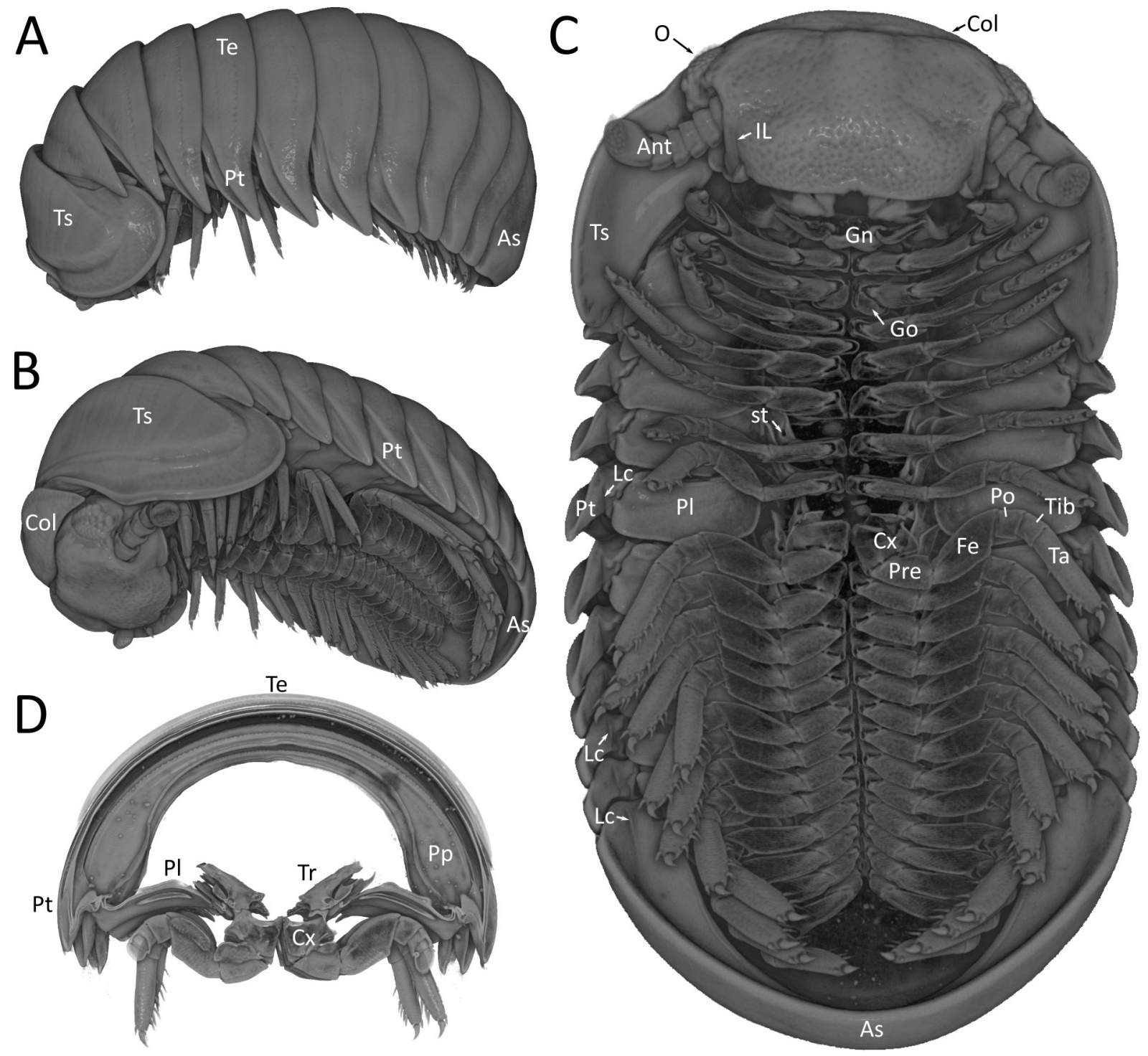

Fig. 12. Zephronia viridisoma Rosenmejer \& Wesener sp. nov., paratype, $q$ (ZFMK MYR8787), volume rendering based on micro-computed tomography. Stored as cybertype under https://doi.org/10.5281/zenodo.4548243. A. Habitus, lateral view. B. Habitus, ventro-lateral view. C. Habitus, ventral view. D. Body-ring architecture, cross section trough midbody-ring. Abbreviations: Ant = Antennae; $\mathrm{As}=$ anal shield; ts = thoracic shield; $\mathrm{Col}=$ collum; $\mathrm{Cx}=\mathrm{Coxa} ; \mathrm{Fe}=$ femur; $\mathrm{Gn}=$ gnathochilarium; $\mathrm{Go}=$ gonopore; $\mathrm{IL}=$ incisura lateralis; $\mathrm{Lc}=$ locking carina; $\mathrm{O}=$ ommatidia; $\mathrm{Pl}=$ pleurite; $\mathrm{Po}=$ postfemur, $\mathrm{Pp}=$ prophragma; $\mathrm{Pre}=$ prefemur; $\mathrm{Pt}=$ paratergite; $\mathrm{st}=$ stigma, $\mathrm{Ta}=$ tarsus; $\mathrm{Te}=$ tergite; $\mathrm{Tib}=$ tibia; $\mathrm{Tr}=$ tracheal apodeme; $\mathrm{ts}=$ thoracic shield. Not to scale. 
Verhoeff, 1924 (see Mauriès 2001 for a revision), while in Sphaeropoeus the third podomere of the anterior telopod has a characteristic process (see Wesener $2016 \mathrm{~b}$ for a revision). Genetically, S. aesculus sp. nov. does group, albeit weakly supported (Fig. 1), with a specimen of an unknown genus from Malaysia. Therefore, $S$. aesculus sp. nov. is either a distant branch of Sphaerobelum, with potentially additional species occurring in southern Thailand or Malaysia, or belongs to an as yet undescribed genus.

\section{Intra- and interspecific distances of the COI gene}

The barcoding studies of Zephroniidae giant pill-millipedes are currently biased towards interspecific distances, as only a few intraspecific sequences, often from the same locality, are available. Therefore any interpretation of intraspecific genetic variation in species of the Zephroniidae is currently difficult. The $6.1 \% \mathrm{p}$-distance in the COI barcoding gene observed between the two different populations of S. aesculus sp. nov. are certainly high for intraspecific distances, higher than the up to $5 \%$ observed in the geographically widespread European pill millipede species Glomeris marginata (Villers, 1789) and G. klugii Brandt, 1833 (Reip \& Wesener 2018; Wesener \& Conrad 2016). Only future studies, once females of the species become available from the type locality, or male specimens from Khao Luang, will show if the $6.1 \%$ correspond to intra- or interspecific distances. The observed interspecific distances of the two new Thai Zephroniidae species towards related species are slightly higher (minimum 16.8\%) than those observed in giant pill-millipedes from Madagascar, where the species of Sphaeromimus de Saussure \& Zehntner, 1902 show interspecific distances of 8.3-20.8\% (Wesener et al. 2014; Moritz \& Wesener 2017), while the interspecific distances in the less well-sampled genus Zoosphaerium are 9.120\% (Sagorny \& Wesener 2017; Wesener \& Anilkumar 2020; Wesener \& Sagorny 2021). One reason behind the large interspecific distances in our two new species from southern Thailand might be that their closest relatives have not been discovered or sampled yet.

\section{Acknowledgements}

Many thanks to the curator Peter Schwendinger (MHNG) for loaning out their substantial giant pillmillipede collection. Claudia Etzbauer (ZFMK) provided invaluable help and advise in the molecular lab. Karin Ulmen (ZFMK) advised and helped at the scanning electron microscope. Thorsten Klug (ZFMK) made the multi-layer photographs. We thank the German Research Foundation (DFG) for funding within the scope of the project "Phylogeny of the Diplopoda: micro-CT scans, morphology and morphometry of all millipede orders" (DFG WE 2479/4-1) by Alexander Blanke and TW. We also thank the editor Nesrine Akkari and the reviewers Sergei Golovatch, Natdanai Likhitrakarn and Oliver Macek for their constructive reviews of the manuscript. The ZFMK hosted TR for her stay in Bonn. This study is part of TR's Master thesis conducted at the University of Copenhagen.

\section{References}

Altschul S.F., Madden T.L., Schäffner A.A., Zhang J., Zhang Z., Miller W. \& Lipman D.J. 1997. Gapped BLAST and PSIBLAST: a new generation of protein database search programs. Nucleic Acids Research 25 (17): 3389-3402. https://doi.org/10.1093/nar/25.17.3389

Astrin J.J. \& Stüben P.E. 2008. Phylogeny in cryptic weevils: molecules, morphology and new genera of western Palaearctic Cryptorhynchinae (Coleoptera: Curculionidae). Invertebrate Systematics 22: 503522. https://doi.org/10.1071/IS07057

Clements R., Sodhi NS., Schilthuizen M. \& Ng P.K. 2006. Limestone karsts of Southeast Asia: imperiled arks of biodiversity. Bioscience 56 (9): 733-742.

https://doi.org/10.1641/0006-3568(2006)56[733:LKOSAI]2.0.CO;2

Enghoff H. 2005. The millipedes of Thailand (Diplopoda). Steenstrupia 29: 87-103. 
Enghoff H., Sutcharit C. \& Panha S. 2007. The shocking pink dragon millipede, Desmoxytes purpurosea, a colourful new species from Thailand (Diplopoda: Polydesmida: Paradoxosomatidae). Zootaxa 1563: 31-36. https://doi.org/10.11646/zootaxa.1563.1.3

Enghoff H., Golovatch S., Short M., Stoev P. \& Wesener T. 2015. Diplopoda. In: Minelli A. (ed.) Treatise on Zoology - Anatomy, Taxonomy, Biology. The Myriapoda 2 (16): 363-453.

Hall T.A. 1999. BioEdit: a user-friendly biological sequence alignment editor and analysis program for Windows 95/98/NT. Nucleic Acids Symposium Series 41: 95-98.

Hebert P.D., Cywinska A., Ball S.L. \& Dewaard J.R. 2003. Biological identifications through DNA barcodes. Proceedings of the Royal Society of London. Series B: Biological Sciences 270 (1512): 313321. https://doi.org/10.1098/rspb.2002.2218

Hirst A.S. 1907. On four new pill-millipedes from the Malay Peninsula and Siam. Annals and Magazine of Natural History Series 7 20: 215-219, pl. 10. https://doi.org/10.1080/00222930709487327

Jeekel C.A.W. 2000. A new genus of Sphaeropoeidae from Malaysia (Diplopoda, Sphaerotheriida). Myriapod Memoranda 2: 68-70.

Karsch F. 1881. Neue Juliden des Berliner Museums, als Prodromus einer Juliden-Monographie. Zeitschrift für die gesamten Naturwissenschaften, Dritte Folge 6: 3-79.

Likhitrakarn N., Golovatch S.I., Srisonchai R. \& Panha S. 2019. A new species of the millipede genus Cryptocorypha Attems, 1907, from northern Thailand (Polydesmida, Pyrgodesmidae). ZooKeys 833: 121-132. https://doi.org/10.3897/zookeys.833.32413

Likhitrakarn N., Golovatch S.I., Srisonchai R. \& Sutcharit C. 2021. Two new species of the giant pillmillipede genus Zephronia Gray, 1832 from Thailand (Diplopoda: Sphaerotheriida: Zephroniidae). Tropical Natural History 21: 12-26.

Limaye A. 2012. Drishti: a volume exploration and presentation tool. In: Developments in X-ray Tomography VIII. Proceedings SPIE 8506: 85060X. International Society for Optics and Photonics. https://doi.org/10.1117/12.935640

Mauriès J.-P. 2001. Sur l'identité de Zephronia hainani Gressit, 1941, à propos de la description d'un nouveau Prionobelum (Diplopoda, Sphaerotheriida, Sphaeropoeidae) de Hainan, Chine. Zoosystema 23 (1): 131-142.

Moritz L. \& Wesener T. 2017. Integrative description of two new species of Malagasy chirping giant pillmillipedes, genus Sphaeromimus (Diplopoda, Sphaerotheriida, Arthrosphaeridae). European Journal of Taxonomy 381: 1-25. https://doi.org/10.5852/ejt.2017.381

Nei M. \& Kumar S. 2000. Molecular Evolution and Phylogenetics. Oxford University Press, New York.

Pimvichai P., Enghoff H., Panha S. \& Backeljau T. 2018. Morphological and mitochondrial DNA data reshuffle the taxonomy of the genera Atopochetus Attems, Litostrophus Chamberlin and Tonkinbolus Verhoeff (Diplopoda: Spirobolida: Pachybolidae), with descriptions of nine new species. Invertebrate Taxonomy 32: 159-195. https://doi.org/10.1071/IS17052

Pimvichai P., Enghoff H., Panha S. \& Backeljau T. 2020. Integrative taxonomy of the new millipede genus Coxobolellus, gen. nov. (Diplopoda: Spirobolida: Pseudospirobolellidae), with descriptions of ten new species. Invertebrate Systematics 34 (6): 591-617. https://doi.org/10.1071/IS20031

QGIS Development Team 2018. QGIS Geographic Information System. Open Source Geospatial Foundation Project. Available from http://qgis.osgeo.org [accessed 27 Jul. 2021].

Reip H.S. \& Wesener T. 2018. Intraspecific variation and phylogeography of the millipede model organism, the black pill millipede Glomeris marginata (Villers, 1789) (Diplopoda, Glomerida, 
ROSENMEJER T. et al., New giant pill-millipedes from southern Thailand

Glomeridae). In: Stoev P. \& Edgecombe G.D. (eds) Proceedings of the $17^{\text {th }}$ International Congress of Myriapodology, Krabi, Thailand. ZooKeys 741: 93-131. https://doi.org/10.3897/zookeys.741.21917

Sagorny C. \& Wesener T. 2017. Two new giant pill-millipede species of the genus Zoosphaerium endemic to the Bemanevika area in northern Madagascar (Diplopoda, Sphaerotheriida, Arthrosphaeridae). Zootaxa 4263 (2): 273-294.

Schindelin J., Arganda-Carreras I., Frise E., Kaynig V., Longair M., Pietzsch T., Preibisch S., Rueden C., Saalfeld S., Schmid B., Tinevez J.-Y., White D.J., Hartenstein V., Eliceiri K., Tomancak P. \& Cardona A. 2012. Fiji: an open-source platform for biological-image analysis. Nature methods 9 (7): 676-682. https://doi.org/10.1038/nmeth.2019

Semenyuk I., Golovatch S.I. \& Wesener T. 2018. Four new species of giant pill-millipedes from Vietnam (Sphaerotheriida: Zephroniidae). Zootaxa 4459 (3): 535-550.

https://doi.org/10.11646/zootaxa.4459.3.7

Semenyuk I., Golovatch S.I. \& Wesener T. 2020. Some new or poorly-known Zephroniidae (Diplopoda, Sphaerotheriida) from Vietnam. ZooKeys 930: 37-60. https://doi.org/10.3897/zookeys.930.47742

Srisonchai R., Enghoff H., Likhitrakarn N., Sutcharit C. \& Panha S. 2016. Four colourful new species of dragon millipedes, genus Desmoxytes Chamberlin, 1923, from northern Thailand (Diplopoda: Polydesmida: Paradoxosomatidae). Zootaxa 4170 (1): 93-113.

https://doi.org/10.11646/zootaxa.4170.1.4

Tamura K., Stecher G., Peterson D., Filipski A. \& Kumar S. 2013. MEGA6: molecular evolutionary genetics analysis version 6.0. Molecular Biology and Evolution 30 (12): 2725-2729.

https://doi.org/10.1093/molbev/mst197

Wesener T. 2016a. The giant pill-millipedes, order Sphaerotheriida - An annotated species catalogue with morphological atlas and list of apomorphies (Arthropoda: Diplopoda). Bonn Zoological Bulletin Supplementum 63: 1-104.

Wesener T. 2016b. Redescription and phylogenetic analysis of the type species of the giant pill-millipede genus Sphaeropoeus Brandt, 1833 (Diplopoda, Sphaerotheriida, Zephroniidae). Zootaxa 4184 (1): 141157. https://doi.org/10.11646/zootaxa.4184.1.9

Wesener T. 2019. First records of giant pill-millipedes from Laos (Diplopoda, Sphaerotheriida, Zephroniidae). Zootaxa 4563 (2): 201-248. https://doi.org/10.11646/zootaxa.4563.2.1

Wesener T. \& Anilkumar P.A. 2020. The millipedes collected by the Museum "La Specola" on Madagascar 1989/1991, with the description of three new species of giant pill-millipedes (Diplopoda, Sphaerotheriida, Arthrosphaeridae). ZooKeys 930: 3-35. https://doi.org/10.3897/zookeys.930.47620

Wesener T. \& Conrad C. 2016. Local hotspots of endemism or artifacts of incorrect taxonomy? The status of microendemic pill millipede species of the genus Glomeris in Northern Italy (Diplopoda, Glomerida). PLoS ONE 11 (9): e0162284. https://doi.org/10.1371/journal.pone.0162284

Wesener T. \& Sagorny C. 2021. Seven new giant pill-millipede species and numerous new records of the genus Zoosphaerium from Madagascar (Diplopoda, Sphaerotheriida, Arthrosphaeridae). European Journal of Taxonomy 758 (1): 1-48. https://doi.org/10.5852/ejt.2021.758.1423

Wesener T., Minh-Tu Le D. \& Loria S.F. 2014. Integrative revision of the giant pill-millipede genus Sphaeromimus, with the description of seven new species (Diplopoda, Sphaerotheriida, Arthrosphaeridae). ZooKeys 414: 67-104. https://doi.org/10.3897/zookeys.414.7730

Wesener T., Wongthamwanich N. \& Moritz L. 2021. Description of the first species of Glomeridesmida from Thailand (Diplopoda, Glomeridesmida, Glomeridesmidae). Zookeys 1024: 137-156.

https://doi.org/10.3897/zookeys.1024.63678 
Wongthamwanich N., Panha, S. Sierwald, P. Wesener T. \& Thirakhupt K. 2012. A new species of the giant pill-millipede genus Sphaerobelum Verhoeff, 1924 from northern Thailand, with an extensive description and molecular characters (Diplopoda: Sphaerotheriida: Zephroniidae). Zootaxa 3220: 2943. https://doi.org/10.11646/zootaxa.3220.1.2

Wongthamwanich N., Panha S., Sitthicharoenchai D., Pradatsundarasar A., Seelanan T., Enghoff H. \& Thirakhupt K. 2013 (for 2012). Daily activities of the giant pill-millipede Zephronia $\mathrm{cf}$. viridescens Attems, 1936 (Diplopoda: Sphaerotheriida: Zephroniidae) in a deciduous forest in Northern Thailand. Zoological Studies 51: 913-926.

Zhao Y., Yu J., \& Liu W. 2020. A molecular-based phylogeny of the millipede genus Sphaerobelum Verhoeff, 1924, with the first record of the genus from mainland China (Diplopoda: Sphaerotheriida: Zephroniidae). Annales de la Société entomologique de France (NS) 56 (4): 341-348.

Manuscript received: 19 February 2021

Manuscript accepted: 21 June 2021

Published on: 11 August 2021

Topic editor: Nesrine Akkari

Desk editor: Pepe Fernández

Printed versions of all papers are also deposited in the libraries of the institutes that are members of the EJT consortium: Muséum national d'histoire naturelle, Paris, France; Meise Botanic Garden, Belgium; Royal Museum for Central Africa, Tervuren, Belgium; Royal Belgian Institute of Natural Sciences, Brussels, Belgium; Natural History Museum of Denmark, Copenhagen, Denmark; Naturalis Biodiversity Center, Leiden, the Netherlands; Museo Nacional de Ciencias Naturales-CSIC, Madrid, Spain; Real Jardín Botánico de Madrid CSIC, Spain; Zoological Research Museum Alexander Koenig, Bonn, Germany; National Museum, Prague, Czech Republic.

\section{Supplementary material}

Supp. file 1. Estimates of Evolutionary Divergence between Sequences. The number of base differences per site from between sequences are shown. The analysis involved 34 nucleotide sequences. Codon positions included were $1^{\text {st }}+2^{\text {nd }}+3^{\text {rd }}$. All ambiguous positions were removed for each sequence pair. There were a total of 674 positions in the final dataset. Evolutionary analyses were conducted in MEGA6 (Tamura et al. 2013). https://doi.org/10.5852/ejt.2021.762.1457.4821 